\title{
"Ceria"
}

Jurnal Pendidikan Anak Usia Dini

ISSN 2301-9905

Volume 10, No. 1, Juli 2019

Fakultas Keguruan dan Ilmu Pendidikan- Universitas Muhammadiyah Tangerang

\section{Upaya Meningkatkan Kosakata Bahasa Inggris Melalui Metode Bernyanyi Pada Anak Usia 5-7 Tahun di TK Kharisma Global School Kec. Panunggangan Barat Kab. Tangerang}

\author{
${ }^{1}$ Yulia Alfiani, ${ }^{2}$ Yayah Rukhiyah \\ Program Studi Pendidikan Guru Pendidikan Anak Usia Dini; Fakultas Keguruan Dan \\ Ilmu Pendidikan; Universitas Muhammadiyah Tangerang \\ Email : ${ }^{1}$ yuliaalfiani2107@gmail.com, ${ }^{2 y}$ ayahrukhiyah@rocketmail.com
}

\begin{abstract}
ABSTRAK
Penelitian ini bertujuan untuk meningkatkan kosakata bahasa Inggris anak melalui kegiatan bernyanyi. Penelitian ini dilatarbelakangi adanya permasalahan hambatan dalam kemampuan penguasaan kosakata yaitu dimana anak sangat sulit menghafal kata-kata bahasa Inggris yang disampaikan guru, terutama untuk menghafal katakata yang lebih dari satu suku kata, serta adanya kesalahan-kesalahan atau ketidaktepatan dalam menjawab arti yang dimaksud dalam pembelajaran bahasa Inggris. Metode yang digunakan adalah Penelitian Tindakan Kelas yang dilakukan melalui 3 siklus, siklus terdiri atas perencanaa (planning), tindakan (acting), pengamatan (observing), dan refleksi (reflecting). Subjek penelitian adalah 9 anak kelompok B yang belum maksimal memahami kosakata bahasa Inggris. Teknik pengumpulan data melalui catatan lapangan, catatan wawancara dan dokumentasi foto kegiatan. Pembelajaran Bahasa Inggris melalui metode bernyanyi ini merupakan suatu metode pembelajaran yang sederhana karena dalam pembelajaran ini, anak dimudahkan dalam menghafal kosakata Bahasa Inggris secara tidak langsung sehingga dapat meningkatkan kemampuan penguasaan kosakata bahasa terutama Bahasa Inggris. Dengan metode bernyanyi anak-anak akan dapat mengungkapkan isi pikiran dan perasaan melalui nada dan kata - kata. Metode bernyanyi merupakan salah satu kegiatan yang bisa menumbuhkan semangat anak untuk belajar, karena metode bernyanyi dapat dilakukan sambil bermain dengan prinsip pembelajaran di TK. Kemampuan kosakata bahasa Inggris anak pada siklus I mencapai 40\%, pada siklus II meningkat mencapai $67 \%$ dan meningkat lebih baik lagi pada siklus III yaitu $89 \%$. Dengan demikian dapat disimpulkan bahwa variasi dalam pembelajaran memiliki peranan penting dalam meningkatkan kemampuan kosakata bahasa Inggris dengan metode bernyanyi.
\end{abstract}

Kata Kunci : Kosakata Bahasa Inggris, Metode Bernyanyi, Anak usia 5-7 tahun 


\section{Pengantar}

Dunia pendidikan adalah suatu upaya untuk mencerdaskan kehidupan bangsa dan meningkatkan mutu sumber daya manusia. Peningkatan mutu pendidikan dilakukan dengan cara pemberian pengetahuan atau yang disebut dengan pengajaran pada kehidupan seorang manusia yang dimulai sejak dini. Pengajaran sebagai pengetahuan yang diperoleh anak pertama kali adalah dengan memahami apa yang dilakukan orang tuanya baik gerak tubuh maupun bahasa yang diucapkan. Jadi anak akan secara langsung belajar melalui lingkungan sosialnya yakni lingkungan awal seorang anak berkembang. Anak akan berinteraksi dan berkomunikasi secara langsung dengan lingkungannya memahami diri sendiri dan orang lain melalui pengamatan, penglihatan, pendengaran, maupun pengalamannya sendiri, adalah satunya melalui bahasa (Santrock 1995, h.176).

Menurut Jamaris $(2012,78)$ karakteristik kemampuan bahasa anak usia 5-6 tahun adalah sudah dapat mengucapkan lebih dari 2.500 kosakata. Perkembangan kosakata anak merupakan salah satu aspek bahasa yang sangat penting. Semakin banyak kosakata yang dimiliki anak, maka semakin banyak juga kemampuan anak dalam menggunakan bahasa. Dengan mengembangkan penguasaan kosakata sejak kecil, maka secara perlahan-lahan anak menguasai kosakata, h ini akan berpengaruh pada banyaknya kosakata yang dimiliki anak sesuai dengan tingkat perkembangan bahasa yang digunakan.

Berdasarkan observasi yang dilakukan oleh peneliti yang terjadi di TK Kharisma Global anak belum mampu menguasai 2.500 kata, di TK kharisma anak hanya memiliki \pm 100 kosakata bahasa Inggris. Pengajaran yang kurang menarik dalam mengajarkan kosakata bahasa Inggrisdan guru hanya terpaku pada pengajaran membaca, menulis, dan berhitung (Calistung).Setiap harinya anak hanya diberi pelajaran membaca, menulis, dan berhitung (Calistung) tanpa adanya pengajaran kosakata bahasa Inggris. Di TK Kharisma Global School belum sepenuhnya mampu mengaplikasikan kosakata bahasa Inggriskarena pembelajaran bahasa Inggrisdi TK kharisma hanya 1 minggu sekali dengan metode pemberian tugas terhadap anak, jadi 
anak hanya diberikan lembar kerja dan anak mengerjakan tugas, seperti menghubungkan gambar dengan tulisan. Sehingga anak dalam kesehariannya belum mampu menguasai banyak kosakata bahasa Inggris.Stimulasi yang diberikan kepada anak belum mampu membuat anak menguasai kosakata bahasa Inggris karena anak hanya diberikan lembar kerja dan metode bercerita menggunakan buku cerita bahasa Inggris hanya seminggu sekali maka dari itu membuat kosakata anak sangat rendah karena stimulasi yang diberikan guru kurang.

Dalam penelitian ini peneliti memilih Maka dari itu penulis membuat metode bernyanyi untuk meningkatkan kosakata bahasa Inggrispada anak usia 5-7 tahun karena dengan bernyanyi anak dapat merasa senang. Mengacu pada metode yang telah diuraikan di atas, peneliti menganggap bahwa metode bernyanyi merupakan metode yang dianggap tepat untuk anak usia dini, karena metode bernyanyi mengandung unsur nyanyian sekaligus unsur bermain musik di dalamnya. Selain itu musik memiliki peranan penting di TK diantaranya peranan seni sebagai media, media bermain dan media pendidikan.

Bernyanyi pada dasarmya merupakan bakat alamiah yang dimiliki oleh seorang individu bemyanyi merupakan kegiatan yang paling penting bagi anak karena sarana pengungkapan pikiran dan perasaan Menurut kamtini dalam (Risaldy, 2016, h.90) Bernyanyi merupakan sarana pengungkapan pikiran dan perasaan, sebab kegiatan bernyanyi penting bagi pendidikan anak-anak selain itu bernyanyi adalah kegiatan menyenangkan yang memberi kepuasan kepada anak anak Bernyanyi merupakan kegiatan yang sangat digemari oleh anak karena anak anak mendapatkan rasa senang, dapat mengekspresikan perasaannya melalui nyanyian.

Bernyanyi merupakan kata-kata yang dilagukan dengan irama dan nada tertentu, biasanya anak-anak sangat senang bemyanyi, bemyanyi merupakan kegiatan yang hubungannya dengan kehidupan sehari-hari.(Suyanto 2015, h.114).Nyanyian adalah serangakaian kata-kata yang dilagukan dengan irama dan nada 
tertentu.Dengan menyanyikan lagu guru mengajak siswa untuk melakukan kegiatan yang ada bubungannya dengan kehidupan sehari-hari Bernyanyi merupakan kegiatan yang sangat disenangi anak-anak, nyanyian merupakan serangakain kata-kata yang dilagukan dengan nada tertentu dan biasanya ada hubungannya dengan kehidupan sehari-hari.

Dengan demikian, metode bernyanyi merupakan sarana pengungkapan pikiran dan perasaan karena melalui bernyanyi anak-anak merasa senang, dapat mengekspresikan perasaanya melalui bernyanyi sambil menggerakan badannya.Dalam kegiatan bernyanyi bagi anak juga anak-anak mendapatkan kosakata baru dan belajar lagu-lagu baru.

\section{Metode}

Metode penelitian yang digunakan dalam penelitian ini adalah Penelitian Tindakan Kelas (PTK), dengan subjek penelitian yaitu anak kelompok B (usia 5-7 tahun) di TK Kharisma Global School. Menurut Arikunto (2016) Penelitian tindakan kelas adalah penelitian yang memaparkanterjadinyasebab akibat dari perlakuan, sekaligus memaparkan apa saja yangterjadi ketika perlakuan diberikan, dan memaparkan seluruh proses sejak awalpemberian perlakuan sampai dengan dampak dari perlakuantersebut. Bentuk penelitian tindakan yang digunakan dalam penelitian ini adalah penelitian tindakan kolaboratif. Suhardjono (2015) menjelaskan bahwa pada PTK jenis tersebut terdapat kolaborasi atau kerja sama antara peneliti (dalam hal ini mahasiswa, atau dosen, atau peneliti yang lain) dengan praktisi, yakni guru yang akan melakukan proses pembelajaran di saat PTK berlangsung. Dalam penelitian ini kolaborasi dilakukan antara peneliti dan guru kelas, dimana peneliti bertindak sebagai observer dan guru bertindak sebagai pelaksana tindakan. Dalam Penelitian Tindakan Kelas ini, tindakan yang dilakukan adalah meningkatkan kosakata melalui kegiatan montase pada anak usia 5-7 tahun, dengan fokus pada aspek-aspek kosakata antara lain menyebutkan angka, huruf, bagian tubuh, benda disekitarnya, benda-benda langit, 
nama binatang dan nama buah.Desain penelitian yang digunakan adalah model Kemmis dan Taggart, yaitu dilakukan dalam tiga siklus dan tiga tindakan/pertemuan pada setiap siklusnya. Tahapan dalam penelitian ini adalah perencanaan, pelaksanaan tindakan, pengamatan dan refleksi.Instrumen yang digunakan dalam penelitian ini yaitu berupa lembar penilaian berupa daftar checklist, catatan wawancara, catatan lapangan serta dokumentasi.Teknik analisis data yang digunakan adalah berupa data kuantitatif dan data kualitatif.

\section{Hasil Dan Pembahasan}

Peningkatan kosakata anak dalam penelitian ini dilakukan dengan menerapkan metode bernyanyi dalam tiga siklus, setiap siklus terdiri dari tiga pertemuan.Kosakataanak diukur berdasarkan satu indikator yaitu menyebutkan kosakata bahasa Inggris

Penerapan metode bernyanyi yang dilakukan peneliti menggunakan video dan lagu-lagu bahasa Inggris serta membahas tema yang berbeda pada setiap siklus.Pada siklus I tema yang dibahas adalah alam semesta setelah membahas tema anak-anak mulai menonton video lagu-lagu bahasa Inggris lalu mengaplikasikannya melalui nyanyian.

Hasil pengamatan pada siklus I menunjukkan ada beberapa anak dalambernyanyi bahasa Inggris masih harus didampingi oleh guru selama kegiatan bernyanyi, dan malas-malasan dalam menggerakan badannya pada lagu yang ada gerakannya dan anak-anak pun masih bercanda-canda dalam kegiatan bernyanyi.

Tabel 1

\section{Hasil Observasi Kosakata Anak Siklus I}

\begin{tabular}{lllllllllll}
\hline \multirow{2}{*}{ No } & \begin{tabular}{l} 
Nama \\
\cline { 3 - 11 }
\end{tabular} & Anak & \multicolumn{1}{c}{ Indikator } & \multicolumn{3}{c}{ Jumlah } \\
\hline 1 & CH & 1 & 1 & 1 & 2 & 2 & 2 & 3 & 12 & $34 \%$ \\
2 & CL & 2 & 2 & 2 & 2 & 2 & 1 & 1 & 12 & $34 \%$ \\
3 & SH & 3 & 4 & 4 & 4 & 3 & 3 & 4 & 25 & $71 \%$ \\
4 & CR & 4 & 5 & 5 & 3 & 3 & 3 & 4 & 27 & $77 \%$
\end{tabular}




\begin{tabular}{lllllllllll}
5 & SM & 2 & 2 & 2 & 1 & 2 & 3 & 2 & 14 & $40 \%$ \\
6 & DT & 1 & 1 & 1 & 2 & 1 & 1 & 1 & 8 & $23 \%$ \\
7 & SR & 2 & 2 & 1 & 1 & 1 & 1 & 1 & 9 & $26 \%$ \\
8 & RE & 3 & 4 & 4 & 3 & 3 & 3 & 4 & 24 & $69 \%$ \\
9 & LB & 4 & 4 & 5 & 3 & 3 & 3 & 4 & 26 & $74 \%$ \\
\hline
\end{tabular}

Berdasarkan tabel $1 \mathrm{di}$ atas terlihat bahwa kosakata anak pada siklus I telah mencapai persentase sebesar $44 \%$, yaitu dari 9 anak ada 2 anak yang skor kosakatanya telah mencapai indikator keberhasilan yang telah ditentukan. Anak mengalami peningkatan kosakata walaupun sebagian besar anak belum memenuhi kriteria dalam setiap indikator yang diukur.

Berdasarkan hasil observasi dan hasil belajar anak pada siklus II, ditemukan sejumlah permasalahan anak.Pada pelaksanaan tindakan di siklus II, anak-anak sudah mengalami peningkatan.Perkembangan kosakata bahasa Inggris anak di kelompok B TK Kharisma Global School Kabupaten Tangerang mulai berkembang dengan baik, $\mathrm{h}$ ini terlihat beberapa anak yang belum mampu bernyanyi lagu bahasa Inggris hanya beberapa saja yang dapat mengikuti kegiatan bernyanyi.Anak belum mampu mengartikan kosakata bahasa Inggris, menulis kosakata bahasa Inggris dengan baik. Pada saat penelitian, peneliti mengamati hanya beberapa anak saja yang fokus, mengerti dan mengaplikasikan lagu-lagu bahasa Inggris pada siklus II ada 2 orang anak lagi yang sudah dapat mengikuti jika pada pra siklus masih 2 anak yang suda bisa mengikuti maka setelah dilakukan siklus I meningkat lagi menjadi 2 orang anak dan pada siklus II meningkat lagi menjadi 2 anak.

Tabel 2

Hasil Observasi Kosakata Anak Siklus II

\begin{tabular}{lllllllllll}
\hline \multirow{2}{*}{ No } & Nama & \multicolumn{1}{c}{ Indikator } & \multicolumn{3}{c}{ Jumlah } \\
\cline { 2 - 12 } & Anak & \multicolumn{1}{c}{$\mathbf{1}$} & F & \% \\
\hline 1 & CH & 1 & 1 & 1 & 2 & 2 & 2 & 3 & 12 & $34 \%$ \\
2 & CL & 2 & 2 & 2 & 2 & 2 & 1 & 1 & 12 & $34 \%$
\end{tabular}




\begin{tabular}{lllllllllll}
3 & SH & 3 & 4 & 4 & 4 & 3 & 3 & 4 & 25 & $71 \%$ \\
4 & CR & 4 & 5 & 5 & 3 & 3 & 3 & 4 & 27 & $77 \%$ \\
5 & SM & 2 & 2 & 2 & 1 & 2 & 3 & 2 & 26 & $74 \%$ \\
6 & DT & 1 & 1 & 1 & 2 & 1 & 1 & 1 & 27 & $77 \%$ \\
7 & SR & 2 & 2 & 1 & 1 & 1 & 1 & 1 & 9 & $26 \%$ \\
8 & RE & 3 & 4 & 4 & 3 & 3 & 3 & 4 & 24 & $69 \%$ \\
9 & LB & 4 & 4 & 5 & 3 & 3 & 3 & 4 & 29 & $83 \%$ \\
\hline
\end{tabular}

Berdasarkan hasil siklus II menunjukkan adanya peningkatan kosakata bahasa Inggris. Hal ini terbukti dari perbandingan antara siklus I dan siklus II. Dari data terlihat bahwa sebelum diberikan tindakan jumlah anak yang didapat mencapai indikator hanya 4 orang anak, sedangkan data setelah diberikan tindakan naik jadi 6 anak dari 9 Orang anak. Ini menggambarkan bahwa ada kenaikan sekitar $23 \%$ dari siklus I. Refleksi proses pembelajaran yang dilakukan oleh peneliti pada siklus ini menunjukkan hasil yang lebih baik.

Dari hasil di atas dapat diperoleh presentase siklus II sebesar $67 \%$, diterangkan bahwa secara keseluruhan anak belum dapat mencapai indikator keberhasilan yang ditentukan sehingga perlu dilakuakn perbaikan di siklus III.

Tabel 3

Hasil Observasi Kosakata Anak Siklus III

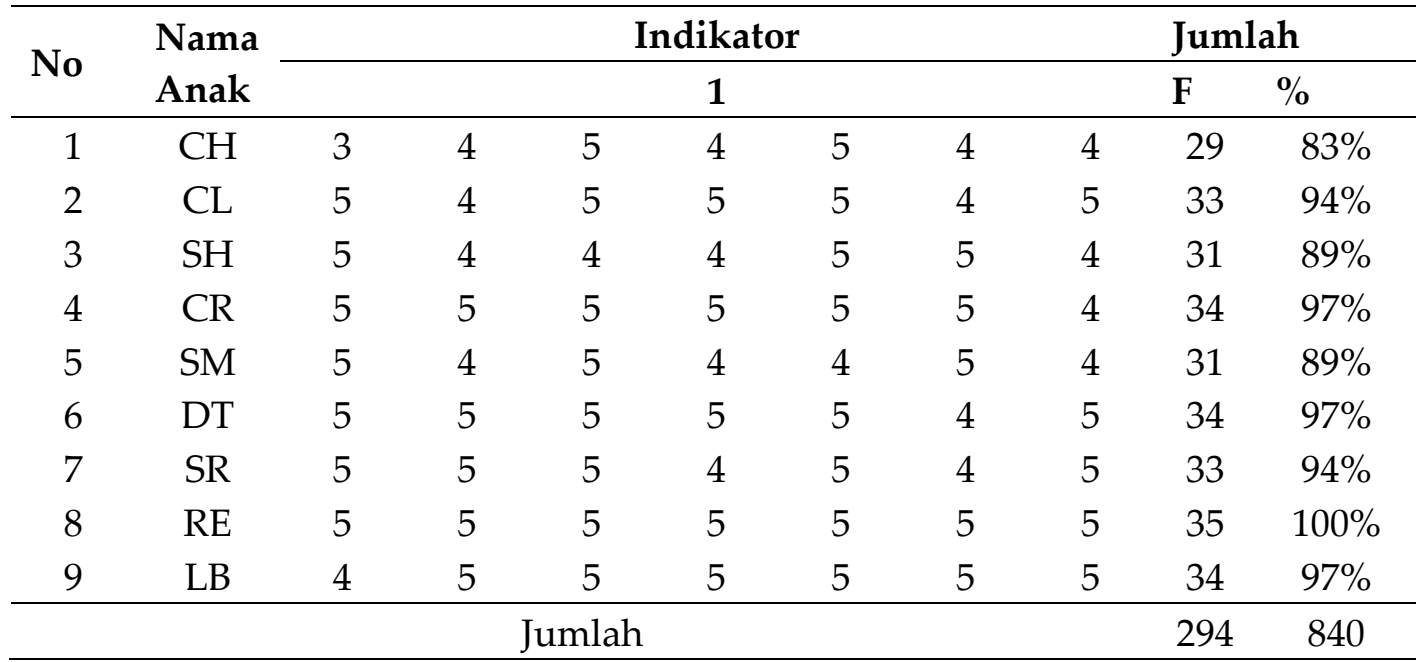


Berdasarkan pelaksanaan kegiatan pembelajaran pada siklus II maka pada siklus III pelaksanaan pembelajaran sudah berjalan dengan baik, ini dapat dilihat pada data dari 9 orang anak sudah meningkat lagi menjadi 2 orang anak yang sudah mencapai indikator hanya 1 orang anak yang belum menguasai kosakata bahasa Inggris.Hal ini dapat dilihat dari persentase perbandingan antara siklus I dan II yaitu $67 \%$,dan pada siklus II dan III menjadi $89 \%$.

Dari hasil tindakan dan kolaborator memutuskan bahwa peneliti berhenti disiklus III, karena perkembangan kosakata bahasa Inggris anak sudah meningkat secara signifikan mulai dari kondisi awal belum sama sekali ada peningkatan, siklus I menjadi $44 \%$, siklus II meningkat menjadi $67 \%$, dan siklus III meningkat menjadi $89 \%$. Dari hasil observasi diketahui bahwa perkembangan kosakata Inggris anak usia 5-6 Tahun di TK Kharisma Global dapat ditingkatkan melalui pembelajaran kosakata bahasa Inggris dengan menggunakan metode bernyanyi.

Berdasarkan paparan hasil data terkait kosakata anak di atas dapat diketahui kegiatan tindakan penelitian yang peneliti lakukan. Hal ini terbukti bahwa pembelajaran dengan metode bernyanyi dapat membantu anak dalam memahami kosakata bahasa Inggris.Kemampuan sangat penting bagi anak untuk mengembangkan potensi nya dalam kemampuan kosakata bahasa Inggris.Bernyanyi merupakan sarana pengungkapan pikiran dan perasaan, sebab kegiatan bernyanyi penting bagi pendidikan anak-anak selain itu bernyanyi adalah kegiatan menyenangkan yang memberi kepuasan kepada anak anak.Bernyanyi merupakan kegiatan yang sangat digemari oleh anak karena anak anak mendapatkan rasa senang, dapat mengekspresikan perasaannya melalui nyanyian.

\section{Kesimpulan}

Berdasarkan hasil penelitian dan pembahasan di bab IV, maka penelitian ini dapat disimpulkan metode bernyanyi pada anak usia 5-7 tahun di TK Kharisma Global School, terjadi peningkatan Kosakata Bahasa Inggris pada anak, ini terlihat dari 
penelitian awal dari 9 orang anak yang belum mampu membaca, menyebutkan, menyimak, menulis dan mendengarkan kosakata bahasa Inggris, setelah melakukan metode bernyanyi, kemampuan kosakata bahasa Inggris anak terjadi peningkatan yang signifikan dan dapat berkembang dengan baik. Tingkat keberhasilan pelaksanaan siklus I adalah $44 \%$ anak sudah mulai aktif mengikuti kegiatan bernyanyi untuk meningkatkan kosakata bahasa Inggris, pada siklus II anak berhasil $67 \%$, sedangkan pada siklus III anak berhasil 89 \%yakni dari siklus I 40\% dari 9 anak. Terbukti dari hipotesis perkembangan kosakata bahasa Inggris pada anak usia 5-7 tahun dengan metode bernyanyi setelah tindakan mengalami peningkatan yang signifikan.Media pembelajaran perlu disiapkan dengan baik agar menumbuhkan minat anak untuk melaksanakan kegiatan.

Berdasarkan kesimpulan di atas, ada beberapa hal penting yang dapat ditindak lanjuti yaitu: 1) Bagi guru dan sekolahmenyediakan media belajar untuk dan sarana prasarana yang sesuai untuk anak usia dini, sehingga anak-anak mudah untuk menerima pembelajaran yang dilaksanakan.Guru juga harus menjadi model pada proses pembelajaran karena anak belajar dari model yang ditampilkan; 2)Bagi orang tua, agar lebih memperhatikan setiap perkembangan dan potensi yang dimiliki anak. Dan memahami pentingnya kosakata bahasa Inggris pada anak dengan memberikan pengajaran yang sesuai dengan suasana yang menyenangkan, dan; 3) Bagi peneliti selanjutnya, peneliti selanjutnya diharapkan memperhatikan dan melengkapi 
instrumen yang digunakan untuk mengukur aspek-aspek kosakata agar mendapatkan hasil yang maksimal.

\section{Daftar Acuan}

Risaldy sabil. (2016) Bermain, Bercerita \& Bernyanyi Bagi Anak usia Dini Jakarta timur : PT Luxima metro media. Rosdakarya

Sudjana, nana (2011).Penilaian Hasil Proses Belajar Mengajar. Bandung: PT Remaja Rosydakarya.

Fridani, dkk. (2014) Evaluasi Perkembangan Anak Usia Dini. Yogyakarta: Universitas Terbuka Depdiknas.

Susanto, Ahmad. (2011). Perkembangan Anak Usia Dini: Pengantar dalam Berbagai Aspeknya. Jakarta: Kencana Prenada Media Group.

Moleong, Lexi. (2012). Metodologi Penelitian Kualitatif. Bandung: Remaja Rosdakarya. Mulyasa.(2014). Praktik penelitian Tindakan Kelas.Bandung : PT Remaja Rosdakarya 